\title{
Wstępne wyniki oceny wybranych klonów maliny właściwej (Rubus idaeus L.) poszerzających zmienność genetyczną pod względem ważnych cech fenotypowych
}

\author{
Preliminary results of the evaluation of selected red raspberry (Rubus idaeus L.) \\ clones so as to extend existing genetic variability in terms of important phenotypic \\ features
}

\section{Agnieszka Masny ${ }^{\varpi}$, Edward Żurawicz ${ }^{\oplus}$, Jolanta Kubik ${ }^{\oplus}$}

Zakład Hodowli Roślin Ogrodniczych, Instytut Ogrodnictwa, ul. Konstytucji 3 Maja 1/3, 96-100 Skierniewice

$\bowtie$ e-mail: agnieszka.masny@inhort.pl

\begin{abstract}
W pracy przedstawiono wyniki badań z roku 2019, czyli z pierwszego roku oceny klonów. Celem badań było określenie możliwości poszerzenia zmienności genetycznej maliny właściwej (Rubus idaeus L.), istniejącej w zasobach genetycznych Instytutu Ogrodnictwa, pod względem takich cech biologicznych, jak okres dojrzewania, atrakcyjność (wygląd), wielkość i masa owoców, wytwarzanie kolców przez rośliny, siła wzrostu i zdrowotność krzewów. Badaniami objęto najbardziej wartościowe genotypy wyselekcjonowane $\mathrm{z}$ populacji 2640 siewek pokolenia $\mathrm{F}_{1}$, otrzymanych ze skrzyżowania w układzie diallelicznym, wg II metody Griffinga (Griffing, 1956) 10 odmian maliny ('Canby', 'Glen Ample', 'Laszka', 'Polana', 'Polka', 'Radziejowa', 'Schönemann', 'Sokolica', 'Veten' i 'Willamette'). Uzyskane wyniki badań potwierdziły, że możliwe jest poszerzenie zmienności genetycznej przy zastosowaniu metod hodowli konwencjonalnej, a także połączenie w jednym genotypie takich cech maliny, jak zdolność do wytwarzania wysokiej jakości owoców, wydłużone letnio-jesienne owocowanie i bezkolcowość pędów.
\end{abstract}

Słowa kluczowe: genotypy maliny czerwonej, hodowla konwencjonalna, hodowla krzyżówkowa, hodowla twórcza maliny, hybrydyzacja, selekcja,

\begin{abstract}
The aim of the study was to determine the possibility of extending the genetic variability of red raspberry (Rubus idaeus L.) stock existing in the genetic resources of the Research Institute of Horticulture in terms of such biological characteristics as ripening time, attractiveness (appearance), size and weight of fruit, spine production by plants, growth vigour and health of shrubs. The paper presents the results of research from 2019, i.e. the first year of clone evaluation. The study includes the most valuable genotypes selected from a population of 2640 seedlings of the $F_{1}$ generation, obtained from hybridization made in a diallel system, according to the Griffing II method (Griffing, 1956) of 10 cultivars of raspberry ('Canby', 'Glen Ample', 'Laszka', 'Polana', 'Polka', 'Radziejowa', 'Schönemann', 'Sokolica', 'Veten' and 'Willamette'). The obtained test results confirmed that it is possible to broaden genetic variability using conventional breeding methods, as well as to combine in one genotype such features of raspberry as the ability to produce high quality fruit, extend summer-autumn fruiting and produce spineless shoots.
\end{abstract}

Key words: conventional breeding, creative raspberry breeding, cross breeding, hybridization, red raspberry genotypes, selection

\section{Wstęp}

Owoce maliny właściwej (Rubus idaeus), potocznie zwanej czerwoną, należą do grupy najbardziej delikatesowych owoców świata, o bardzo wszechstronnym wykorzystaniu. Są wyśmienite jako świeże owoce deserowe i doskonałe na dżemy, kompoty, soki, mrożonki i cenne dodatki smakowe do różnych wyrobów (lody, czekolady, cukierki, herbaty itp.). Maliny zawierają wiele substancji odżywczych, niezbędnych do prawidłowego funkcjonowania organizmu ludzkiego, jak witaminy A, B2 (ryboflawina),
B3 (niacyna), B6, B9 (kwas foliowy), C (kwas askorbinowy), E i K, czy takie pierwiastki, jak potas, magnez, wapń, sód, żelazo i cynk (Burton -Freeman i in., 2016). Wielką zaleta malin jest ich niska kaloryczność, $100 \mathrm{~g}$ świeżych malin to tylko $52 \mathrm{kcal}$. Ponadto owoce te, ze względu na zawartość kwasu elagowego (Markowski i Płocharski, 2011), charakteryzującego się właściwościami antybakteryjnymi, wspomagają leczenie przeziębień i grypy. Znane jest również ich działanie antyoksydacyjne, antykancerogenne i przeciwdziałające wolnym rodnikom, 
dzięki dużej zawartości związków fenolowych, w tym antocyjanów i elagitannin (Castilho Maro $\mathrm{i}$ in., 2013; Burton-Freeman $\mathrm{i}$ in., 2016).

Polska od wielu lat jest czołowym w świecie producentem i eksporterem malin - świeżych, mrożonych i ich przetworów. W ostatnich latach średnio rocznie produkujemy około 120 tys. ton malin (w roku 2019, z uwagi na suszę było to tylko około 75 tys. ton) (GUS 2019). Polska jest więc największym w świecie producentem tych owoców (obok Serbii), a produkcja malin cały czas rozwija się. W szybkim tempie rośnie powierzchnia malin uprawianych pod osłonami wysokimi (uprawa sterowana na zbiór przyspieszony i opóźniony). Dużą część malin produkowanych w Polsce dostarczają odmiany hodowli Instytutu Ogrodnictwa. Przez wiele lat szczególnie cenną była ,powtarzająca” odmiana 'Polka' (Danek i Markowski, 2003; Danek 2012), która owocuje w okresie letnio-jesiennym. Oprócz takich zalet, jak wysoka plenność, dobra zimotrwałość, atrakcyjny kształt i wygląd oraz dobry smak owoców, odmiana ta posiada także wady. Należy do nich wysoka podatność roślin i owoców na wirusa o nazwie Raspberry Bushy Dwarf Virus (RBDV), który powoduje krzaczastą karłowatość roślin oraz nierównomierne dojrzewanie i deformację owoców, zwane też rozpadaniem się owoców maliny właściwej (Żurawicz i Cieślińska 2005; Tzanetakis i in. 2007; Muster 2008). Wirus ten rozprzestrzenia się nie tylko z porażonym materiałem roślinnym, ale także z pyłkiem kwiatów i poprzez zainfekowane nasiona. Nie ma możliwości zwalczania tego patogena na plantacji, a straty $\mathrm{z}$ powodu porażenia roślin są duże i mają charakter narastający (Moore i Hoashi-Erhardt, 2012; Paszko, 2012; Paszko i in., 2018). Wadą roślin tej odmiany jest też silna kolcowatość (kolczastość) pędów. Cecha ta znacząco utrudnia prace pielęgnacyjne, a zwłaszcza zbiór owoców. Za wadę odmiany 'Polka' uznaje się też intensywnie czerwoną barwę skórki jej owoców. Powoduje to, że po krótkim okresie przetrzymywania, np. ekspozycji na półkach w supermarketach, owoce 'Polki' stwarzają wrażenie przejrzałych.

Informacje dostępne w literaturze fachowej wskazują, że są już genotypy maliny właściwej o różnej porze dojrzewania owoców, charakteryzujące się wytwarzaniem jasnoczerwonych owoców, małą podatnością na RBDV, zróżnicowanym terminem dojrzewania i bezkolcowością pędów (Jones i McGavin, 2004; Moore i Martin, 2008). Oznacza to, że możliwe jest poszerzenie istniejącej zmienności genetycznej w obrębie gatunku Rubus idaeus poprzez zastosowanie konwencjonalnych metod hodowli. Jest więc możliwe uzyskanie nowych genotypów, łączących w sobie różne, pożądane cechy biologiczne, w tym bardzo ważne z użytkowego punktu widzenia, jak zróżnicowana pora dojrzewania, dobra jakość zewnętrzna i wewnętrzna owoców, mała podatność/tolerancja roślin na groźne choroby wirusowe, czy bezkolcowość i w ten sposób wzbogacenie genetycznej i fenotypowej różnorodności w obrębie gatunku Rubus idaeus.

Celem badań jest sprawdzenie hipotezy zakładającej, że w oparciu o użyte w badaniach odmiany i zastosowane techniki hodowli konwencjonalnej, możliwe jest poszerzenie istniejącej zmienności genetycznej w obrębie gatunku Ribes idaeus i wykorzystanie jej jako źródła genów do tworzenia nowych odmian maliny czerwonej. Prawdopodobieństwo uzyskania takich innowacyjnych genotypów jest bardzo duże, ponieważ użyte w badaniach odmiany maliny pochodzą z różnych regionów świata i różnią się pod względem bardzo wielu cech biologicznych, co potwierdzają wyniki badań, również polskich (Żurawicz, 2016a, 2016b, 2017, 2018; Żurawicz i in., 2017, 2018).

\section{Materiały i Metody}

Wyjściowym materiałem roślinnym w badaniach była populacja mieszańców (siewek) pokolenia $\mathrm{F}_{1}$, otrzymanych $\mathrm{w}$ roku 2014 ze skrzyżowania w układzie diallelicznym, wg II metody Griffinga (Griffing, 1956) dziesięciu odmian maliny właściwej. Wykaz oraz krótką charakterystykę tych odmian zamieszczono w Tabeli 1, zaś schemat krzyżowań - w Tabeli 2.

Badana populacja siewek rosła w doświadczeniu na polu doświadczalnym Sadu Pomologicznego Instytutu Ogrodnictwa w Skierniewicach. Doświadczenie to założono wiosną 2015 roku w układzie bloków losowych, w czterech powtórzeniach, z 12 roślinami na poletku, w rozstawie $0,4 \mathrm{~m}$ $\times 2,0 \mathrm{~m}$. Łącznie było to 2640 siewek, należących do 45 rodzin mieszańców, otrzymanych w wyni$\mathrm{ku}$ kontrolowanych krzyżowań form rodzicielskich oraz do 10 rodzin mieszańców, otrzymanych na drodze samozapylenia tych form. Pielęgnacja roślin w doświadczeniu była zgodna z zaleceniami dla plantacji produkcyjnych maliny właściwej w Polsce.

W latach 2016-2017 oceniono wszystkie mieszańce (siewki) i ich formy rodzicielskie pod względem następujących cech: plonowanie (typ owocowania), wybrane cechy owoców (wygląd czyli atrakcyjność i wielkość), masa owoców, siła wzrostu roślin, pokrój roślin oraz kolczastość pędów. 
BIULETYN IHAR Nr 291 / 2020

Wykaz oraz krótka charakterystyka odmian użytych w programie krzyżowań

List and brief description of the cultivars used in the crossing program

\begin{tabular}{|c|c|c|c|c|c|c|c|c|}
\hline $\begin{array}{c}\text { Nazwa } \\
\text { odmiany } \\
\text { Cultivar name }\end{array}$ & $\begin{array}{c}\text { Kraj } \\
\text { pochodz. } \\
\text { Country } \\
\text { of the origin }\end{array}$ & $\begin{array}{l}\text { Rodowód } \\
\text { Pedigree }\end{array}$ & $\begin{array}{c}\text { Pora } \\
\text { dojrzewania } \\
\text { Ripening time }\end{array}$ & $\begin{array}{c}\text { Plenność } \\
\text { Productivity }\end{array}$ & $\begin{array}{l}\text { Wielkość } \\
\text { owoców } \\
\text { Fruit size }\end{array}$ & $\begin{array}{l}\text { Barwa owo- } \\
\text { ców } \\
\text { Fruit colour }\end{array}$ & $\begin{array}{c}\text { Podatność } \\
\text { na RBDV } \\
\text { RBDV } \\
\text { susceptibility }\end{array}$ & $\begin{array}{c}\text { Obecność } \\
\text { kolców } \\
\text { na pędach } \\
\text { Presence } \\
\text { of spines } \\
\text { on shoots }\end{array}$ \\
\hline Canby* & USA & $\begin{array}{c}\text { Viking } \times \\
\text { Lloyd George }\end{array}$ & $\begin{array}{c}\text { dość } \\
\text { wczesna }\end{array}$ & wysoka & średnie & $\begin{array}{l}\text { żywo czer- } \\
\text { wone }\end{array}$ & podatna & + \\
\hline Glen Ample* & UK & $\begin{array}{c}\text { Brak infor- } \\
\text { macji }\end{array}$ & $\begin{array}{l}\text { średnio-wcze- } \\
\text { sna }\end{array}$ & wysoka & duże & $\begin{array}{l}\text { jasno czer- } \\
\text { wone }\end{array}$ & mało podatna & - \\
\hline Laszka* & POL & $80408 \times 80192$ & wczesna & wysoka & bardzo duże & $\begin{array}{c}\text { jasno } \\
\text { czerwone }\end{array}$ & podatna & + \\
\hline Polana** & POL & $\begin{array}{c}\text { Heritage } \times \\
\text { Eva Herbster- } \\
\text { nte }\end{array}$ & $\begin{array}{c}\text { połowa } \\
\text { VIII }\end{array}$ & dość wysoka & średnie & $\begin{array}{l}\text { żywo czer- } \\
\text { wone } \\
\text { z silnym poły- } \\
\text { skiem }\end{array}$ & mało podatna & + \\
\hline Polka** & POL & $\begin{array}{c}\text { Autumn } \\
\text { Bliss }+ \text { Lloyd } \\
\text { George }+R \text {. } \\
\text { crataeifolius }\end{array}$ & VII/VIII & wysoka & $\begin{array}{l}\text { średnie } \\
\text { i duże }\end{array}$ & $\begin{array}{c}\text { żywo czerwo- } \\
\text { ne z silnym } \\
\text { połyskiem }\end{array}$ & $\begin{array}{l}\text { bardzo po- } \\
\text { datna }\end{array}$ & + \\
\hline Radziejowa* & POL & $92271 \times 96221$ & $\begin{array}{c}\text { wczesna } \\
\text { (druga połowa } \\
\text { VI) }\end{array}$ & dość wysoka & duże & $\begin{array}{l}\text { żywo czer- } \\
\text { wone }\end{array}$ & podatna & + \\
\hline Schönemann* & GER & $\begin{array}{l}\text { Lloyd Georg } \times \\
\text { Preussen }\end{array}$ & $\begin{array}{l}\text { bardzo } \\
\text { późna }\end{array}$ & wysoka & bardzo duże & $\begin{array}{l}\text { ciemno- } \\
\text { czerwone }\end{array}$ & mało podatna & + \\
\hline Sokolica* & POL & $96131 \times 96221$ & $\begin{array}{c}\text { średnio } \\
\text { wczesna }\end{array}$ & wysoka & duże & $\begin{array}{c}\text { jasno czer- } \\
\text { wone }\end{array}$ & podatna & + \\
\hline Veten* & NOR & $\begin{array}{c}\text { Asker } \times \\
\text { Lloyd George }\end{array}$ & wczesna & $\begin{array}{l}\text { średnia do wy- } \\
\text { sokiej }\end{array}$ & $\begin{array}{l}\text { średnie } \\
\text { i duże }\end{array}$ & $\begin{array}{l}\text { czerwone } \\
\text { i ciemno } \\
\text { czerwone }\end{array}$ & mało podatna & + \\
\hline Willamette* & USA & $\begin{array}{l}\text { Lloyd George } \\
\times \text { Newburgh }\end{array}$ & późna & wysoka & duże & $\begin{array}{l}\text { żywo czer- } \\
\text { wone }\end{array}$ & $\begin{array}{l}\text { toleran- } \\
\text { cyjna }\end{array}$ & + \\
\hline
\end{tabular}

Objaśnienie: *-odmiana tradycyjna (letnia); **-odmiana „powtarzajaca” (letnio-jesienna)

Explanation: * - traditional (summer) cultivar; ** - "repeating” cultivar (summer-autumn)

Tabela 2

Table 2

Schemat krzyżowania wybranych form rodzicielskich maliny właściwej

Diagram of crossing of selected raspberry parental forms

\begin{tabular}{|c|c|c|c|c|c|c|c|c|c|c|}
\hline & Canby & Glen Ample & Laszka & Polana & Polka & Radziejowa & Schönemann & Sokolica & Veten & Willamette \\
\hline Canby & $x x$ & $\mathrm{x}$ & $\mathrm{x}$ & $\mathrm{x}$ & $\mathrm{x}$ & $\mathrm{x}$ & $\mathrm{x}$ & $\mathrm{x}$ & $\mathrm{x}$ & $\mathrm{x}$ \\
\hline Glen Ample & & $\mathrm{xx}$ & $\mathrm{x}$ & $\mathrm{x}$ & $\mathrm{x}$ & $\mathrm{x}$ & $\mathrm{x}$ & $\mathrm{x}$ & $\mathrm{x}$ & $\mathrm{x}$ \\
\hline Laszka & & & $\mathrm{xx}$ & $\mathrm{x}$ & $\mathrm{x}$ & $\mathrm{x}$ & $\mathrm{x}$ & $\mathrm{x}$ & $\mathrm{x}$ & $\mathrm{x}$ \\
\hline Polana & & & & $\mathrm{xx}$ & $\mathrm{x}$ & $\mathrm{x}$ & $\mathrm{x}$ & $\mathrm{x}$ & $\mathrm{x}$ & $\mathrm{x}$ \\
\hline Polka & & & & & $\mathrm{xx}$ & $\mathrm{x}$ & $\mathrm{x}$ & $\mathrm{x}$ & $\mathrm{x}$ & $\mathrm{x}$ \\
\hline Radziejowa & & & & & & $\mathrm{xx}$ & $\mathrm{x}$ & $\mathrm{x}$ & $\mathrm{x}$ & $\mathrm{x}$ \\
\hline Schönemann & & & & & & & $\mathrm{xx}$ & $\mathrm{x}$ & $\mathrm{x}$ & $\mathrm{x}$ \\
\hline Sokolica & & & & & & & & $\mathrm{xx}$ & $\mathrm{X}$ & $\mathrm{x}$ \\
\hline Veten & & & & & & & & & $x x$ & $\mathrm{x}$ \\
\hline Willamette & & & & & & & & & & $\mathrm{xx}$ \\
\hline
\end{tabular}

Objaśnienie: ㅇ -forma mateczna, ô -forma ojcowska; $x$ - krzyżowanie wprost, xx-samozapylenie

Explanation: + - maternal form, ô- paternal form; $x$ - straight crossing, $x x$ - selfing 
W wyniku przeprowadzonej oceny roślin w doświadczeniu, oznaczono (wyselekcjonowano) siewki najbardziej wyróżniające się pod względem ocenianych cech, mogące poszerzać zmienność genetyczną, zachowywaną w zasobach genowych maliny Instytutu. W roku 2017 dokonano rozmnożenia (rozklonowania) wyselekcjonowanych genotypów, w taki sam sposób rozmnożono ich formy rodzicielskie. Otrzymane klony oraz ich formy rodzicielskie wiosną 2018 roku posadzono w kolekcji klonów, w Sadzie Pomologicznym Instytutu Ogrodnictwa w Skierniewicach. Wszystkie klony $\mathrm{i}$ ich formy rodzicielskie były reprezentowane przez trzy rośliny, rosnące $\mathrm{w}$ rozstawie $0,4 \mathrm{~m} \times 2,5 \mathrm{~m}$.

Rok 2019 był pierwszym rokiem pełnego owocowania roślin w kolekcji klonów i zarazem ich pierwszej szczegółowej oceny. Obejmowała ona takie cechy, jak:

- typ owocowania - L-odmiana letnia, J - odmiana jesienna, L-D - odmiana letnia dwupiętrowa (mająca zdolność do wytworzenia owoców także w wierzchołkowej części pędu pierwszego roku, owoce te mogą stanowić plon handlowy), L-D-P - odmiana letnia dwupiętrowa późna (mająca zdolność do wytworzenia owoców także w wierzchołkowej części pędu pierwszego roku, ale owoce te powstają bardzo późno, nie dorastają i dlatego nie stanowią plonu handlowego);

- wygląd owoców (wielkość i atrakcyjność uwzględniająca jednolitość i regularność kształtu owoców, barwę i jej jednolitość, a także natężenie połysku) - ocena w skali bonitacyjnej 1-9, w której 1 to najniższa, zaś 9 to najwyższa wartość cechy;

- masa owoców - iloraz plonu i liczby owoców w końcu drugiego tygodnia (dojrzewania) zbiorów;

- obecność lub brak kolców na pędach;

- wysokość krzewów - pomiar najwyższego pędu w krzewie;

- zdrowotność krzewów - ocena w skali bonitacyjnej 1-3, w której 3 to najwyższa wartość cechy (najwyższa zdrowotność).

\section{Wyniki}

Rezultatem wykonanej oceny było wskazanie 39 klonów, które zdaniem oceniających, mają najwyższy potencjał do poszerzenia istniejącej zmienności genetycznej maliny utrzymywanej w zasobach genowych Instytutu. Ich wykaz, numery oraz wyniki oceny wraz z wynikami analogicznej oceny form rodzicielskich padano w Tabeli 3.

Jak pokazują wyniki zawarte w Tabeli 3 , oceniane klony bardzo różnią się pod względem ocenianych cech. Spośród nich, tylko dziewięć genotypów (23,1\% populacji klonów) to klony typowo letnie (oznaczone w Tab. 3 literą L), owocujące tylko w okresie wczesnego lata (czerwiec/lipiec). Nieco więcej, bo 14 klonów $(35,9 \%)$ to klony o jesiennym charakterze owocowania (J), owocujące $\mathrm{w}$ miesiącach sierpień i wrzesień, a nawet jeszcze w październiku. Pozostałe 15 klonów $(38,5 \%)$ to genotypy jesienno-letnie (L-D, tzn. LetnieDwupiętrowe). Mają one zdolność do wydawania owoców jesienią w górnej części wysokich pędów młodych (tegorocznych) oraz z uwagi na swoją wysokość, także wczesnym latem w roku następnym, w dolnej części tych samych pędów. Z morfologicznego punktu widzenia takie genotypy można nazywać malinami dwupiętrowymi, bo w pierwszym roku wydają owoce w górnej części (górne piętro) pędu, a w drugim roku $\mathrm{w}$ dolnej części (dolne piętro) tego samego pędu. Jednakże sześć klonów z tej grupy zaliczono do podgrupy oznaczonej w Tabeli 3 jako L-D-P, czyli Letnie-Dwupiętrowe-Późne. U tych klonów owoce na górnym piętrze młodego pędu powstają późnym latem idlatego na ogół nie dojrzewają. Do grupy genotypów o takim charakterze wzrostu i owocowania zaliczono też cztery odmiany rodzicielskie badanych klonów, czyli 'Veten', 'Canby', 'Laszka' i 'Sokolica' oraz odmianę standardową 'Przehyba'. Wymienione odmiany $\mathrm{z}$ agrotechnicznego punktu widzenia uznawane są za odmiany typowo letnie, ale mają zdolność do wytwarzania kwiatostanów i zawiązków owocowych na wierzchołkach młodych (tegorocznych) pędów.

Owoce ocenianych klonów charakteryzują się na ogół dobrą zewnętrzną jakością, określaną ich atrakcyjnością i wielkością. Cechy te oceniano w skali bonitacyjnej 1-9 i za wartościowe uznano jedynie te klony, których owoce dla obu cech uzyskały ocenę co najmniej $6 \mathrm{w}$ przyjętej skali bonitacyjnej, w trakcie dwukrotnej oceny. Ważną informacją jest także przeciętna masa zbieranych owoców. Pod tym względem wyróżniały się klony o numerach M-52, M-412, M-206, M-378, M-336, M-402 oraz M-363, u których średnia masa owoców była wyższa niż 4 g. Owoce o największej masie wytwarzał klon M-206, przeciętna masa jego owoców to $6,2 \mathrm{~g}$, była ona wyraźnie większa niż przeciętna masa owoców rodzicielskiej odmiany 'Glen Ample' (5,7 g).

Oceniane klony różniły się też stopniem kolczastości pędów, ale tylko osiem genotypów (20,5\% populacji tych klonów) to klony bezkolcowe. Były nimi klony o numerach M-217, M-258, M-397, M-271, M-378, M-47 oraz M-255. 
Table 3

Wykaz i charakterystyka najwartościowszych klonów, potencjalnie poszerzających zmienność genetyczną zasobów genowych maliny wlaściwej w Instytucie Ogrodnictwa (z uwzględnieniem odmian rodzicielskich / standardowych)

List and characteristics of the most valuable clones, potentially extending the genetic variability of red raspberry genetic resources at the Research Institute of Horticulture (including parental / standard cultivars)

\begin{tabular}{|c|c|c|c|c|c|c|c|c|c|}
\hline \multirow{2}{*}{$\begin{array}{c}\mathrm{Nr} \\
\text { klonu } \\
\text { Clone } \\
\text { number }\end{array}$} & \multirow[t]{2}{*}{$\begin{array}{l}\text { Rodowód } \\
\text { Pedigree }\end{array}$} & \multirow{2}{*}{$\begin{array}{c}\text { Typ } \\
\text { owocowania } \\
\text { Ripening } \\
\text { type } \\
\text { L, J, L-D, } \\
\text { L-D-P* }\end{array}$} & \multicolumn{3}{|c|}{$\begin{array}{c}\text { Cechy owoców } \\
\text { (atrakcyjność, wielkość) } \\
\text { Fruit characters } \\
\text { (atractiveness, size) } * *\end{array}$} & \multirow{2}{*}{$\begin{array}{c}\text { Masa } \\
\text { owoców } \\
\text { Fruit } \\
\text { weight } \\
(\mathrm{g}) \\
* * *\end{array}$} & \multirow{2}{*}{$\begin{array}{l}\text { Kolce } \\
\text { Spines } \\
(+/-)\end{array}$} & \multirow{2}{*}{$\begin{array}{l}\text { Wysokość } \\
\text { krzewów } \\
\text { Shrub height } \\
\text { (cm) }\end{array}$} & \multirow{2}{*}{$\begin{array}{c}\text { Zdrowot- } \\
\text { ność krzewów } \\
\text { Shrub healthi- } \\
\text { ness } \\
(1-3)^{* * * *}\end{array}$} \\
\hline & & & $\begin{array}{l}15 . \mathrm{VI} \\
(\mathrm{a}, \mathrm{w})\end{array}$ & $\begin{array}{l}\text { 29.VIII } \\
(\mathrm{a}, \mathrm{w})\end{array}$ & $\begin{array}{l}20 . I X \\
(a, w)\end{array}$ & & & & \\
\hline M-7 & Polana $\times$ Schönemann & L-D & 7,7 & 6,5 & & 3,8 & + & 135 & 3 \\
\hline M-104 & Canby $\times$ Polana & L- D & 7,7 & & 7,7 & 3,1 & + & 115 & 3 \\
\hline M-52 & Polana $\times$ Sokolica & $\mathrm{J}$ & & & 7,8 & 4,7 & + & 120 & 3 \\
\hline M-115 & Polka $\times$ Radziejowa & L-D & 8,8 & 7,7 & 8,7 & 2,7 & + & 150 & 2 \\
\hline M-42 & Polka $\times$ Sokolica & $\mathrm{J}$ & 8,7 & & & 3,2 & + & 115 & 2,5 \\
\hline M-57 & Polka $\times$ Sokolica & $\mathrm{J}$ & 7,7 & 8,8 & 7,7 & 2,9 & + & 115 & 3 \\
\hline M-95 & Laszka $\times$ Radziejowa & $\mathrm{L}$ & 8,8 & & & 3,3 & + & 205 & 2 \\
\hline M-164 & Polka $\times$ Radziejowa & L-D & 8,7 & & 8,8 & 3,0 & + & 155 & 3 \\
\hline M-140 & Polka $\times$ Polka & $\mathrm{J}$ & 7,7 & 7,7 & 7,7 & 3,5 & + & 60 & 3 \\
\hline M-217 & Polka $\times$ Sokolica & $\mathrm{L}$ & 8,7 & 5,7 & 6,6 & 2,6 & - & 105 & 3 \\
\hline M-258 & Glen Ample $\times$ Sokolica & $\mathrm{L}$ & 7,6 & & & 3,2 & - & 235 & 3 \\
\hline M-412 & $\begin{array}{c}\text { Glen Ample } \times \\
\text { Radziejowa }\end{array}$ & $\mathrm{L}$ & 7,7 & & & 4,5 & + & 255 & 2 \\
\hline M-341 & Laszka $\times$ Schönemann & L-D-P & 8,7 & & & 3,6 & $+/-$ & 210 & 3 \\
\hline M-345 & Canby $\times$ Polana & L-D & 9,7 & 9,8 & 9,9 & 3,2 & $+/-$ & 215 & 2,5 \\
\hline$M-410$ & $\begin{array}{l}\text { Radziejowa } \times \\
\text { Schönemann }\end{array}$ & $\mathrm{L}$ & 7,7 & & & 3,5 & + & 150 & 3 \\
\hline M-311a & Glen Ample $\times$ Polana & L-D & 6,6 & & & 2,8 & $+/-$ & 180 & 3 \\
\hline M-397 & Canby $\times$ Sokolica & L-D-P & & & & 2,4 & - & 225 & 3 \\
\hline M-271 & Laszka $\times$ Sokolica & $\mathrm{L}$ & 6,6 & & & 2,4 & - & 210 & 3 \\
\hline M-278 & Radziejowa $\times$ Sokolica & $\mathrm{L}$ & 9,7 & & & 3,7 & + & 115 & 3 \\
\hline M-198 & Radziejowa $\times$ Veten & L-D-P & 9,7 & & & 3,3 & + & 160 & 3 \\
\hline M-208 & Radziejowa $\times$ Veten & $\mathrm{L}$ & 8,8 & & & 3,6 & + & 185 & 3 \\
\hline M-206 & Glen Ample $\times$ Polka & L-D-P & 7,7 & & & 6,2 & + & 160 & 2,5 \\
\hline M-293 & Polana $\times$ Sokolica & $\mathrm{J}$ & 8,8 & 7,7 & 7,6 & 3,5 & + & 160 & 2,5 \\
\hline M-317 & Glen Ample $\times$ Polana & L-D & 8,7 & & 8,8 & 3,7 & + & 180 & 2 \\
\hline M-378 & Glen Ample $\times$ Polka & $\mathrm{J}$ & & 6,7 & 7,7 & 4,4 & - & 155 & 3 \\
\hline M-336 & Polana $\times$ Sokolica & $\mathrm{J}$ & 9,8 & & 6,5 & 4,3 & + & 110 & 3 \\
\hline M-388 & Radziejowa $\times$ Veten & $\mathrm{L}$ & 8,9 & & & 3,9 & + & 190 & 2 \\
\hline M-14 & Polana $\times$ Veten & $\mathrm{J}$ & 7,8 & 7,8 & 7,7 & 3,0 & + & 140 & 3 \\
\hline M-402 & Laszka $\times$ Polka & L-D-P & 8,8 & & & 4,5 & + & 200 & 3 \\
\hline M-363 & Radziejowa $\times$ Sokolica & L-D-P & 8,7 & & & 4,2 & + & 180 & 3 \\
\hline
\end{tabular}

Objaśnienie:

* - L-odmiana letnia, J - odmiana jesienna, L-D - odmiana letnia dwupiętrowa (mająca zdolność do wytworzenia owoców także w wierzcholkowej części pędu pierwszego roku, owoce te moga stanowić plon handlowy), L-D-P - odmiana letnia dwupiętrowa późna (majaca zdolność do wytworzenia owoców także w wierzchołkowej części pędu pierwszego roku, ale owoce te powstaja bardzo późno, nie dorastają i dlatego nie stanowia plonu handlowego).

**-a-atrakcyjność owoców, w-wielkość owoców; ocena w skali bonitacyjnej 1-9, w której 9 to najwyższa wartość cechy.

***- iloraz masy owoców w końcu drugiego tygodnia (dojrzewania) zbiorów i liczby owoców

**** - zdrowotność krzewów w skali bonitacyjnej 1-3, w której 3 to najwyższa wartość cechy (najwyższa zdrowotność). 
Tabela 3 cd.

Table 3 cd.

Wykaz i charakterystyka najwartościowszych klonów, potencjalnie poszerzających zmienność genetyczną zasobów genowych maliny właściwej w Instytucie Ogrodnictwa (z uwzględnieniem odmian rodzicielskich / standardowych)

List and characteristics of the most valuable clones, potentially extending the genetic variability of red raspberry genetic resources at the Research Institute of Horticulture (including parental / standard cultivars)

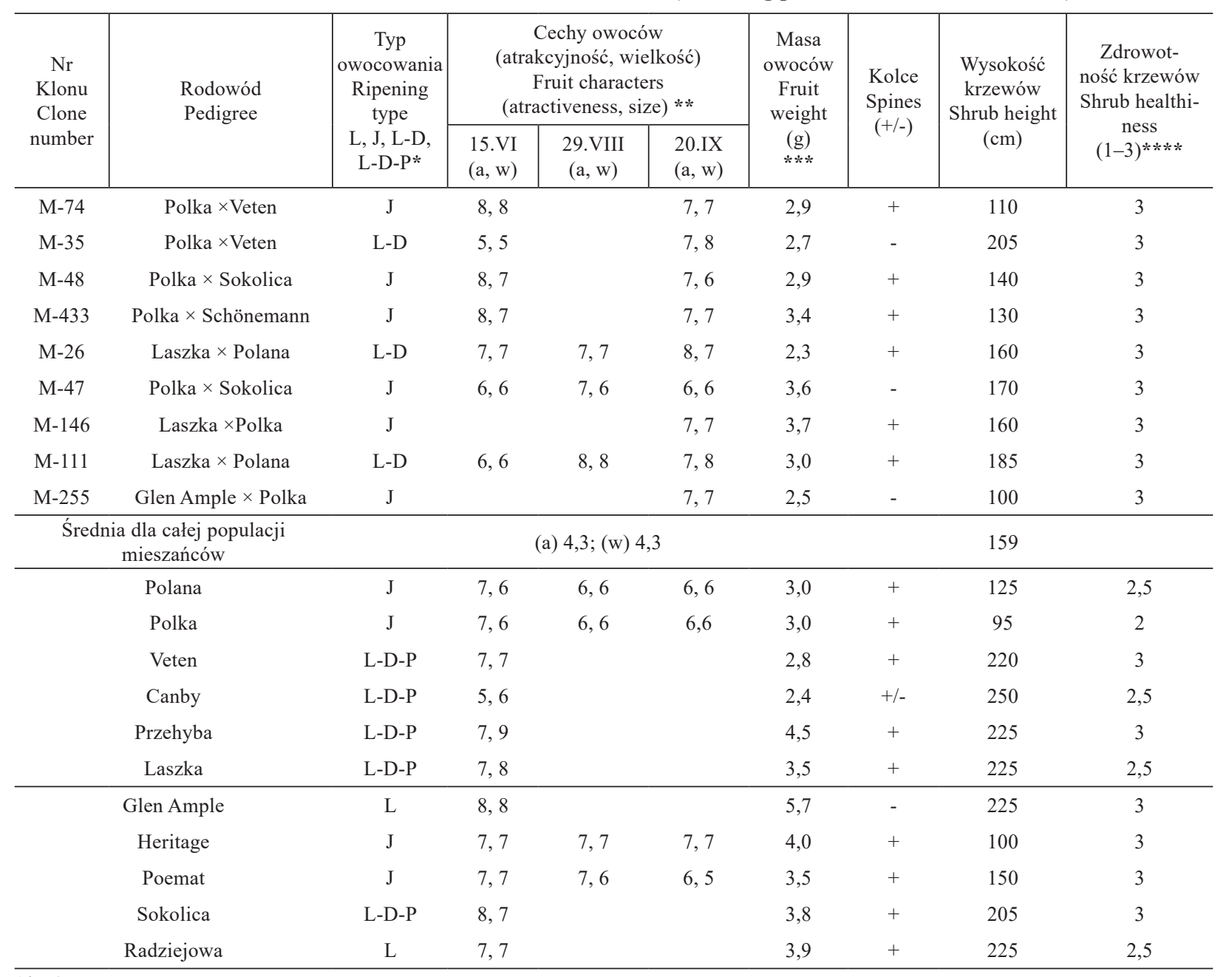

Objaśnienie:

* - L-odmiana letnia, J - odmiana jesienna, L-D - odmiana letnia dwupiętrowa (mająca zdolność do wytworzenia owoców także w wierzchołkowej części pędu pierwszego roku, owoce te moga stanowić plon handlowy), L-D-P - odmiana letnia dwupiętrowa późna (mająca zdolność do wytworzenia owoców także w wierzchołkowej części pędu pierwszego roku, ale owoce te powstają bardzo późno, nie dorastają i dlatego nie stanowia plonu handlowego).

**-a-atrakcyjność owoców, w-wielkość owoców; ocena w skali bonitacyjnej 1-9, w której 9 to najwyższa wartość cechy.

***- iloraz masy owoców w końcu drugiego tygodnia (dojrzewania) zbiorów i liczby owoców

**** - zdrowotność krzewów w skali bonitacyjnej 1-3, w której 3 to najwyższa wartość cechy (najwyższa zdrowotność).

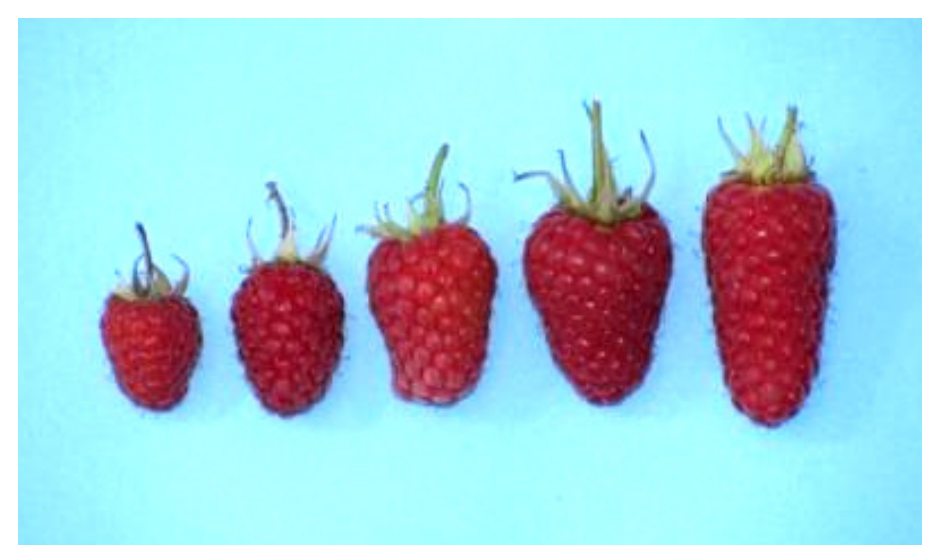

Fot. 1. Różna wielkość i ksztalt owoców maliny właściwej 

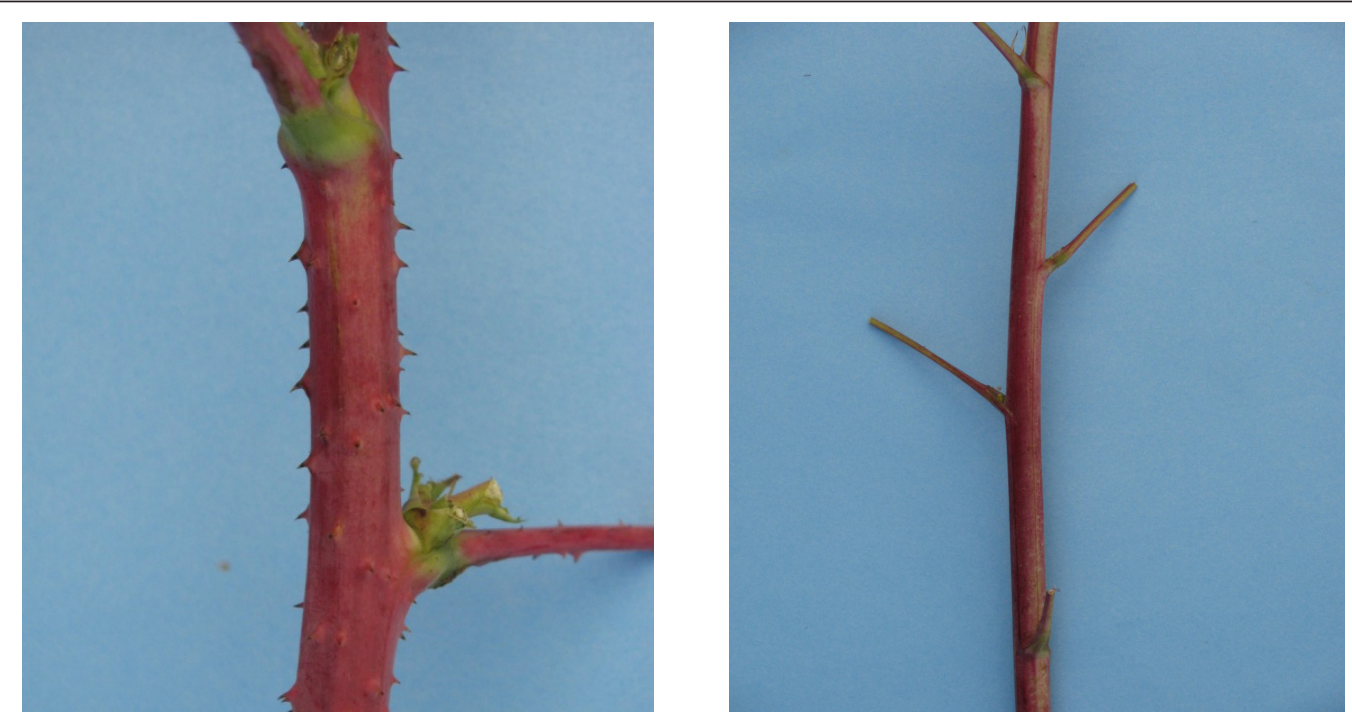

Fot 2. Dwa typy pędów maliny właściwej: kolcowe i bezkolcowe

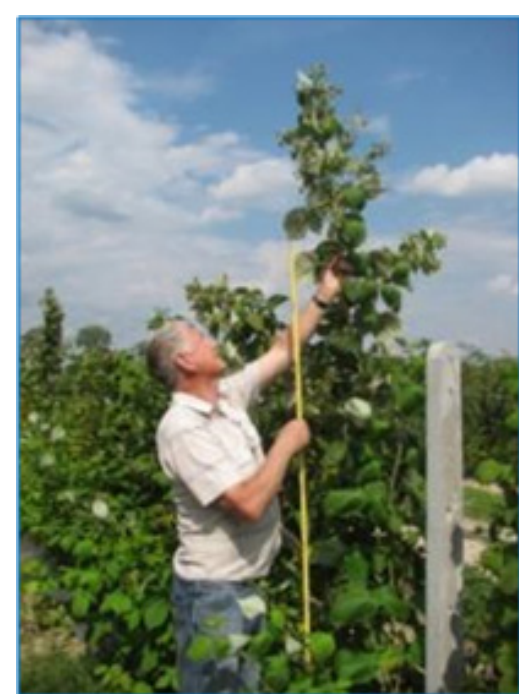

Fot. 3. Różnice w sile wzrostu pędów.

W grupie genotypów bezkolcowych były zarówno klony letnie, jesienne, jak i jesienno -letnie czyli dwupiętrowe, a także rodzicielska odmiana 'Glen Ample'. Natomiast trzy klony, oznaczone numerami M-341, M-345 i M-311a uznano za małokolcowe; w przypadku tych klonów kolce występują tylko w dolnej części pędu, podobnie, jak u rodzicielskiej odmiany 'Canby'.

Jak można było oczekiwać, oceniane klony różniły się też pod względem siły wzrostu pędów. Najsilniejszym wzrostem odznaczały się klony typowo letnie oraz dwupiętrowe, a najsłabszym jesienne. Wysokość tych pierwszych osiągała lub przekraczała poziom $200 \mathrm{~cm}$, podczas gdy przeciętna wysokość klonów jesiennych oscylowała w granicach $150 \mathrm{~cm}$. Podobny wzrost stwierdzono dla odmian rodzicielskich, z tym że w tej grupie odmian najsłabiej rosły pędy jesiennej odmiany 'Polka', u odmiany tej przeciętna wysokość pędów wynosiła jedynie $95 \mathrm{~cm}$.

Ostatnią z ocenianych cech badanych klonów była zdrowotność pędów w krzewie. W przypadku krzewów zdecydowanej większości klonów (79,5\% ich populacji), oceniana zdrowotność była na poziomie 3,0 (według skali bonitacyjnej 1-3), a więc nie zaobserwowano widocznych symptomów porażenia pędów przez choroby czy szkodniki. Tylko w przypadku ośmiu klonów (20,5\% populacji klonów) zdrowotność ta była na poziomie przeciętnym, czyli zawierała się w przedziale 2,0-2,5 punktu w przyjętej skali bonitacyjnej. W sposób dość zbliżony oceniono pod tym względem odmiany rodzicielskie. 


\section{Dyskusja}

Poszerzanie istniejącej zmienności genetycznej w obrębie gatunku Ribes idaeus ma sens, jeżeli $\mathrm{w}$ jednym genotypie możliwe jest połączenie wielu cech biologicznych roślin, które są ważne $\mathrm{z}$ użytkowego punktu widzenia. Za cechy takie w przeprowadzonych badaniach uznano typ owocowania badanych klonów, atrakcyjność, wielkość i masę wytwarzanych owoców, kolczastość pędów, siłę wzrostu krzewów oraz ich zdrowotność. Na to, że połączenie takich cech w jednym genotypie jest możliwe, chociaż dość trudne, wcześniej zwracali uwage Jennings (1988), Jennings i McNicol (1991) i Daubeny (1996), chociaż autorzy ci nie prowadzili szczegółowych badań w tym kierunku. Trudność te łatwo wytłumaczyć jednym z praw Mendla, mówiącym, że cechy dziedzicza się niezależnie. Uzyskanie pożądanego celu, zwłaszcza u roślin wieloletnich, wymaga więc szerokich programów krzyżowań z uwzględnieniem znanych źródeł genów, dużych populacji siewek i czasu, a więc dużych nakładów finansowych.

Tymczasem to właśnie odmiany jesienne dominują w uprawie maliny w Polsce, zwłaszcza 'Polana' i 'Polka' (Danek, 2002). Obie wytwarzają dobrej jakości owoce, ale posiadają obfite i dość agresywne kolce. Kolczastość pędów bardzo utrudnia prace pielęgnacyjne związane z przywiązywaniem pędów do konstrukcji wspierającej (rusztowania) i ich usuwaniem po zbiorach owoców. Kolce utrudniają również zbiór owoców, ponieważ mogą kaleczyć ręce osób zbierających owoce, ale mogą także uszkadzać owoce, w wyniku silnego kołysania owocujących pędów przez wiatr, na co zwracał uwage Daubeny (1996). W przypadku malin jesiennych jest to o tyle istotne, że plantacje takich odmian są prowadzone bez konstrukcji wspierającej rośliny, zapobiegającej nadmiernemu kołysaniu pędów w czasie wietrznej pogody. Warto przy okazji wspomnieć, że obecnie praktycznie wszystkie odmiany jeżyny, uprawiane komercyjnie w świecie to odmiany bezkolcowe, a ogromna większość uprawianych odmian maliny czerwonej to odmiany kolcowe. Są wprawdzie już odmiany bezkolcowe, jak 'Glen Ample', ale udział tej odmiany w produkcji towarowej w Polsce ciągle nie jest wystarczająco wysoki.

Wyniki naszych badań pokazują, że w obrębie dużej populacji siewek i wyselekcjonowanych klonów można znaleźć genotypy bezkolcowe, owocujące w tym samym czasie co polskie odmiany jesienne 'Polka', 'Polana', czy najnowsze 'Poemat' i 'Polonez', ale nie wytwarzające kolców. Nasze bezkolcowe klony, letnie, jesienne, czy jesienno-letnie wytwarzają dobrej jakości owoce - atrakcyjne w wyglądzie i duże, i nie ustępują pod tym względem odmianom rodzicielskim, które w naszych badaniach służą także jako odmiany standardowe.

Jest rzeczą oczywistą, że rośliny maliny czerwonej powinny odznaczać się dobrą siłą wzrostu i małą podatnością na choroby i szkodniki, ale także wysokim stopniem samopłodności, zwłaszcza w przy uprawach w monokulturach odmianowych i w uprawach pod osłonami na zbiór przyspieszony lub opóźniony (Keep, 1968; Daubeny, 1969, 1971; Redalen, 1976; Colbert i de Oliveira, 1990; Żurawicz, 2016a, 2016b; Żurawicz, 2017; Żurawicz, 2018; Żurawicz i in., 2018). Wprawdzie to ostatnie zagadnienie nie było przedmiotem badań ocenianych klonów, ale takie badania będa podjęte w stosunku do najbardziej perspektywicznych klonów.

Rok 2020 będzie drugim rokiem pełnego owocowania ocenianych klonów, co umożliwi weryfikację wyników oceny uzyskanych w roku 2019. Pozwoli to na wybór tych klonów, które w najwyższym stopniu będą łączyć pożądane cechy użytkowe, i w ten sposób poszerzać istniejącą zmienność genetyczną zasobów genowych maliny właściwej Instytutu Ogrodnictwa.

\section{Wnioski}

1. Efektywność krzyżowania użytych w badaniach form rodzicielskich (odmian uprawnych) maliny właściwej jest różna, ale możliwe jest uzyskanie dostatecznie dużej populacji siewek o zróżnicowanych cechach biologicznych.

2. Możliwe jest otrzymanie nowych genotypów, poszerzających istniejącą zmienność genetyczną w obrębie gatunku Rubus idaeus metodą hodowli konwencjonalnej przy wykorzystaniu odmian uprawnych maliny właściwej, różniących się pod względem wielu cech biologicznych.

3. Szczególnie cennym elementem nowej zmienności jest połączenie w jednym genotypie takich cech biologicznych maliny właściwej, jak zdolność do owocowania w terminie letnim, jesiennym i jesienno-letnim, ze zdolnością do tworzenia pędów bez kolców oraz wytwarzaniem wysokiej jakości owoców.

Badania finansowano ze środków projektu MRiRW: Badania podstawowe na rzecz postepu biologicznego w produkcji roślinnej, decyzja HOR.hn.802.4.2019 z dnia 14.05.2019 r., Zadanie $n r 75$. 


\section{Literatura}

Burton-Freeman, B. M., Sandhu, A. K., Eridisinghe, I. (2016). Red raspberries and their bioactive polyphenols: cardiometabolic and neuronal health links. Advances in Nutrition $7(1)$ : 44-65. https://doi.org/10.3945/ an.115.009639

Castilho Maro, L. A., Pio, R., Santos Guedes, M. N., Patto de Abreu, C.M., Nogueira Curi, P. (2013). Bioactive compounds, antioxidant activity and mineral composition of fruits of raspberry cultivars grown in subtropical areas in Brazil. Fruits (68), 209-217.

Colbert, S., de Oliveira, D. (1990). Influence of pollen variety on raspberry (Rubus idaeus L.) development. J. Heredity 81 (6): 434-437.

Danek, J. (2002). 'Polka' and 'Pokusa' - New primocane fruiting raspberry cultivars from Poland. Acta Hort. (585), 197-198.

Danek, J. (2012). Problemy produkcyjne w głównych ośrodkach uprawy malin w świecie. Mat. z konf. „Produkcja owoców miękkich w warunkach niestabilnego rynku”, 26 stycznia 2012, Kraśnik: 40-42.

Danek, J., Markowski, J. (2003). Skład chemiczny owoców wybranych genotypów maliny jako element hodowli jakościowej. I Zjazd Polskiego Towarzystwa Nauk Ogrodniczych nt. „Współczesne ogrodnictwo i jakość życia”, Kraków, 9-11 września 2003. Folia Horticulturae, supl. (2), 397-399.

Daubeny, H. A. (1969). Some variations in self-fertility in the red raspberry. Can. J. Plant Sci. (49), 511-512.

Daubeny, H. A. (1971). Self-fertility in red-raspberry cultivars and selections. J. Amer. Soc. Hort. Sci. 96(5): 588-591.

Daubeny, H. A. (1996). Brambles. In Fruit Breeding. Volume II. Wine and Small Fruits. Ed. Jules Janic, James, N. Moore, John Wiley \& Sons, Inc., New York.

Griffing, B. (1956). A generalised treatments of diallel crosses in quantitative inheritance. Heredity (10), 31-50.

GUS (2019). Wynikowy szacunek zbioru owoców i warzyw, Grudzień 2019.

Jennings, D. L. (1988). Raspberries and blackberries: their breeding, disease and growth. Academic Press. London.

Jennings, D. L., McNicol, R. J. (1991). Rubus breeding: recent progress and problems. Plant Breeding Abstr. (61), 329-340.

Jones, A., McGavin, W. J. (2004). Different rates of spread of Raspberry Bushy Dwarf Virus and some aphid-borne viruses into red raspberry cultivars containing different resistance genes. Acta Hort. (656),149-153.

Markowski, J., Płocharski, W. (2011). Owoce jako źródło składników ważnych dla zdrowia człowieka [W:]. Fizjologia roślin sadowniczych strefy umiarkowanej. Red. nauk. L.S. Jankiewicz, M. Filek, W. Lech. Wydawnictwo Naukowe PWN, Warszawa, s. 438-473.

Moore, P. P., Hoashi-Erhardt, W. K. (2012). Effects of Raspberry
Bushy Dwarf Virus on fruit traits in five raspberry cultivars. Acta Hort. (946), 263-266.

Moore, P. P., Martin, R. R. (2008). Screening for resistance to Raspberry Bushy Dwarf Virus via pollen transmission. Acta Hort. (777), 379-383.

Muster, G. (2008). A survey of the research work on crumbly fruit in red raspberry in Europe. Acta Hort. (777), 505-509.

Paszko, D. (2012). Szanse i zagrożenia opłacalnej produkcji maliny w Polsce. Mat. z konf. „Produkcja owoców miękkich w warunkach niestabilnego rynku”, Kraśnik 26 stycznia (2012), 12-16.

Paszko, D., Krawiec, P., Yareshchenko, A. (2018). Konkurencyjność polskich malin $\mathrm{w}$ porównaniu do serbskich i ukraińskich. XIV Konferencja Sadownicza „Jagodowe trendy", Kraśnik, 7-8 lutego 2018 r.

Redalen, G. (1976). Pollination and fruit set in raspberries. Acta Hort. (60), 169-173.

Tzanetakis, I. E., Halgren, A., Mosier, N., Martin, R. R. (2007). Identification and characterization of Raspberry Mottle Virus, a novel member of the Closteroviridae. Virus Res., (127), 26-33.

Żurawicz, E. (2016)a. Cross-pollination increases the number of drupelets in the fruits of red raspberry (Rubus idaeus L.). Acta Hort. (1133), 145-151; DOI 10.17660/Acta Hortic. 2016.1133.22.

Żurawicz, E. (2016)b. Zapylanie kwiatów a jakość owoców maliny czerwonej w uprawie pod osłonami. Biuletyn Związku Sadowników Rzeczpospolitej Polskiej, XII Międzynarodowa Konferencja Sadownicza „Jagodowe trendy', Kraśnik, 25 - 26 lutego (2016), 92-97.

Żurawicz, E. (2017). Wpływ zapylaczy (źródła pyłku) na wielkość owoców maliny czerwonej w uprawie pod osłonami wysokimi. Biuletyn Związku Sadowników Rzeczpospolitej Polskiej, XIII Międzynarodowa Konferencja Sadownicza ,Jagodowe trendy’, Kraśnik, 19-20 stycznia (2017), 87-93.

Żurawicz, E. (2018). Jedna technologia w uprawie maliny pod osłonami, ale nie jedna odmiana - dlaczego? Informator Biuletyn Związku Sadowników Rzeczpospolitej Polskiej - wydanie specjalne; XIV Międzynarodowa Konferencja Sadownicza „Jagodowe Trendy 2018”, Kraśnik 7-8 lutego (2018), 20-25.

Żurawicz, E., Cieślińska, M. (2005). Rozpadanie się owoców maliny czerwonej. Owoce Warzywa Kwiaty, nr (11), 32-33.

Żurawicz, E., Masny, A., Kubik, J., Lewandowski, M. (2017). Germination of red raspberry seeds as affected by the origin and chemical scarification. Hort. Sci. (Prague) 44 (3): 133-140. DOI: 10.17221/22/2016-HORTSCI.

Żurawicz, E., Studnicki, M., Kubik, J., Pruski, K. (2018). A careful choice of compatible pollinizers significantly improves the size of fruits in red raspberry (Rubus idaeus L.). Scientia Horticulturae (235), 253-257. 